\title{
Bazı kolza (Brassica napus L.) çeşitlerinin Kırşehir ekolojik koşullarında verim ve verim performanslarının değerlendirilmesi
}

\section{Evaluation of yield and yield performance of some winter rapeseed (Brassica napus L.) cultivars in Kırşehir ecological conditions}

\section{İsmail DEMiR ${ }^{1 *}$ (D) \\ ${ }^{1}$ Kırşehir Ahi Evran Üniversitesi, Ziraat Fakültesi, Tarla Bitkileri Bölümü, Kırşehir}

\section{To cite this article:}

Demir, i. (2020). Bazı kolza (Brassica napus L.) çeşitlerinin Kırşehir ekolojik koşullarında verim ve verim performanslarının değerlendirilmesi. Harran Tarım ve Gıda Bilimleri Dergisi, 24(4): 432-439.

DOI:10.29050/harranziraat.694595

Address for Correspondence: Ismail DEMiR

e-mail:

ismail.demir@ahievran.edu.tr

Received Date:

26.02.2020

Accepted Date:

03.11 .2020
(C) Copyright 2018 by Harran University Faculty of Agriculture. Available on-line at www.dergipark.gov.tr/harranziraat
Öz

Araştırma, bazı kolza çeşitlerinin Kırşehir ekolojik koşullarında verim ve verim performanslarının değerlendirilmesi amacıyla, 2014-2015 ve 2015-2016 yetişme sezonunda Kırşehir Ahi Evran Üniversitesi Ziraat Fakültesi deneme tarlalarında gerçekleştirilmiştir. Denemede 8 adet kışlık kolza çeşitleri (Atenzo, Champlain, Elvis, EsMercure, Excalibur, PR46W10, PR46W31, Recordie) kullanılmış ve araştırma tesadüf blokları deneme desenine göre 3 tekerrürlü olarak kurulmuştur. Araştırmada bitki boyu, yan dal sayısı, kapsül sayısı, kapsülde tane sayısı, bin dane ağılığı, tohum verimi, ham yağ oranı ve ham yağ verimi parametreleri incelenmiştir. Araştırmada incelenen özelikler bakımından çeşitler arasında farklııklar gözlenmiş ve bu farklılıklarda istatistiksel anlamda önemli çıkmıştır. Araştırmada ayrıca yıllar arasında önemli farklılıklar gözlenmiş ve bu farklılıklarında 2015-2016 tarım sezonunda sonbahar yağışlarının yetersizliğine bağı kolza bitkisinin kış öncesi yeterli gelişim sağlayamaması ve kış zararının artmasıyla ilişkilendirilmiştir. Bu olumsuz etki nedeniyle tohum ve ham yağ verimi 2014-2015 tarım sezonuna göre yaklaşık \%50 düzeyinde bir azalma göstermiştir. Bitki boyu, yan dal sayısı ve ham yağ oranı yönünden Recordie çeşidi, kapsül ve dane sayısı yönünden ise PR46W31 çeşidi diğer çeşitlere göre daha yüksek değerlere ulaşmıştır. En yüksek verim denemenin ilk yılında PR46W10 (2939.17 kg ha-1) ve PR46W31 (2843.23 $\mathrm{kg} \mathrm{ha}^{-1}$ ) çeşitlerinden elde edilirken ikinci yılında ise, en yüksek tohum verimi EsMercure (1795.37 $\mathrm{kg} \mathrm{ha}^{-1}$ ) çeşidinden elde edilmiştir. Bölge koşulları bir bütün düşünüldüğünde tohum ve ham yağ verimi yönünden EsMercure, Atenzo, PR46W10 ve Recordie çeşitleri önerilmektedir.

Anahtar Kelimeler: Kolza (Brassica napus L), Verim, Yağ oranı, Ham yağ verimi

\section{ABSTRACT}

The research was conducted at experimental field of Kırşehir Ahi Evran University Faculty of Agriculture fields in 2014-2015 and 2015-2016 growing season. Field experiment was designed based on randomized complete block design with three replications and 8 winter rapeseed cultivars (Aten Zo, Champlain, Elvis, Es Mercure, Excalibur, PR46W10, PR46W31, Recordie) were used. Plant height, the number of branches and capsules, seed number per capsule, thousand seed weight, crude oil ratio, seed and oil yield were evaluated in the study. The results revealed that the effect of cultivars was significant on plant height, number of branches and capsules, seed number per capsule, thousand seed weight, crude oil ratio, seed and oil yield. In the study also observed significant differences between years and these differences were associated with the inadequate development of rapeseed plant before 
winter due to insufficient autumn rainfall in the 2015-2016 agricultural season and increased winter cold damage. Due to this negative effect, the seed and crude oil yield decreased by approximately 50\% compared to the 2014-2015 agricultural season result. Recordie cultivar in terms of plant height, side branch number and crude oil ratio, and PR46W31 cultivar in terms of number of capsules and grains reached higher values than other varieties. The highest seed yield was obtained from PR46W10 (2939.17 kg ha-1) and PR46W31 (2843.23 kg ha-1) cultivars in the first year and from EsMercure (1795.37 kg ha-1) cultivar in the second year of research. Considering the regional conditions, EsMercure, Atenzo, PR46W10 and Recordie varieties are recommended in terms of seed and crude oil yield.

Key Words: Rapeseed (Brassica napus L), Seed yield, Oil rate, Oil yield

\section{Giriş}

Bitkisel yağ talebinin karşılanmasında önemli yağlı tohumlu bitkilerden biri olan kolza dünyada 34.7 milyon ha alanda 76.2 milyon ton üretimle soyadan sonra ikinci sırada yer almaktadır (FAO, 2019). Kolza bitkisinin yazlık ve kışlık ekim olanağının olması, ham yağ içeriğinin yüksek olması özellikle biyoyakıt üretiminde tercih edilmesi kolza tarım alanlarının 2006 yılından sonra (27.2 milyon ha) hizla artmasına neden olmuştur. Türkiye'de kolza tarımı ise 2007 yılından sonra önemli artış göstermiş ve 2018 yılında 37.8 bin ha alanda 125 bin ton üretime ulaşarak yağlı tohumlu bitkiler içerinde 3. sırada yer almıştır. Bitkisel yağ talebinin yerli tohum üretimi ile ancak \%30’nu karşıladığımız (TUiK, 2019) düşünüldüğün de alternatif yağlı tohum bitkileri tarımının yaygınlaştırılmasının ülke ekonomisi için ne kadar elzem olduğu görülmektedir. Tohumunda yaklaşık \%45-50 oranında yağ içeren, yağında oleik asit ve omega-3 gibi insan sağlığı için oldukça önemli yağ asitleri barındıran kolza, yağ açı̆̆ının kapatılmasında önemli bitkilerden birisi olabilir. Kolza, kışlık formlarının bulunması, adaptasyon alanının genişliği, toprak isteklerinin azlığı, ekimden hasada kadar mekanizasyona elverişli olması, biyoyakıt olarak kullanıma uygunluğu ve hububat tarımının yapıldığı yerlerde kolayca yetişmesi gibi üstünlükleriyle de üretim deseninde yer alması gereken önemli bir bitkidir (Başalma, 2004, 2006; Gürsoy ve ark., 2015). Kolza bitkisinin kışıı çeşitlerinin ülkemizde uygun iklim koşullarında buğday ile ekim nöbetine girmesi sonucu, ekim nöbeti zenginleşebileceği gibi, yağ açığının kapatılmasında da önemli katkısı olacaktır. Ayrıca, yağ fabrikalarına erken ürün sunmanın yanında yağ işlemi sırasında kabuk ayrımı olmadığından daha kolay ve ekonomik olmaktadır (Başalma, 2004). Küspesinde \%38-40 protein bulunması, erken ve uzun süreli çiçeklenme ile arı ve arıcılara polen sağlaması bakımından çok önemli bir bitkidir. i̇ç Anadolu bölgesi özellikle kışlık kolza ekimine uygun olduğu, sonbaharda erken ekim ile kış donları öncesi 6-8 yaprakla rozet dönemine girmesiyle $-15{ }^{\circ} C^{\prime} y e$ kadar dayanacağı bildirilmektedir (Kolsarıcı ve Başalma, 1988). Bu çalışma ile karasal iklim özelliğinin tam olarak yaşandığı Kırşehir ekolojik koşullarında farklı kışlık kolza çeşitlerinin verim ve verim öğeleri yönünden değerlendirilmesi ve bölgede kışlık kolza tarım olanaklarının oluşturulması ile değerli bir yağlı tohum bitkisinin ekim nöbeti sistemine dahil edilmesi amaçlanmıştır.

\section{Materyal ve Metot}

Araştırma, Kırşehir Ahi Evran Üniversitesi Bağbaşı yerleşkesi Ziraat Fakültesi Uygulama Alanında (3908'17.5"N 3407'01.4"E) $1082.6 \mathrm{~m}$ rakımda, 2014-2015 ve 2015-2016 tarım sezonunda yürütülmüştür.

Çizelge 1. Deneme yerinin toprak özellikleri

Table 1. The results of soil analysis in trial areas

\begin{tabular}{cccccccc}
\hline $\begin{array}{c}\text { Saturasyon } \\
\text { (İşba\%) } \\
\text { Texture }\end{array}$ & $\mathrm{pH}$ & $\mathrm{EC}(\mathrm{mmhos} / \mathrm{cm})$ & $\begin{array}{c}\text { Tuz }(\%) \\
\text { Salinity }\end{array}$ & $\begin{array}{c}\text { Alınabilir } \mathrm{P}_{2} \mathrm{O}_{5} \\
(\%) \\
\text { Available } \mathrm{P}_{2} \mathrm{O}_{5}\end{array}$ & $\begin{array}{c}\text { Kireç } \\
\mathrm{CaCO}_{3} \\
(\%)\end{array}$ & $\begin{array}{c}\text { Alınabilir } \mathrm{K}_{2} \mathrm{O} \mathrm{K} \\
(\mathrm{ppm}) \text { Available } \\
\mathrm{K}_{2} \mathrm{O}\end{array}$ & $\begin{array}{c}\text { Organik } \\
\text { Madde }(\%)\end{array}$ \\
\hline 55 & 7.55 & 0.59 & 0.023 & 0.19 & 21.2 & 63.48 & 1.34 \\
\hline
\end{tabular}


Deneme yerinin toprak analizi sonucuna göre genel olarak killi-tınlı, orta tuzlu, hafif kireçli ve organik maddece fakir bir yapıda olduğu görülmektedir (Çizelge 1).

Deneme yerinin aylık toplam yağış miktarı, nispi nem, aylık ortalama sıcaklık ve toprak üstü minimum sıcaklık verileri Meteoroloji Genel Müdürlüğünden alınmıştır ve Çizelge 2'de verilmiştir.

Çizelge 2. Kırşehir ili 2015-2016 yılı iklim verileri

Table 2. Meteorological data for experimental location during growing season

\begin{tabular}{|c|c|c|c|c|c|c|c|c|c|c|}
\hline \multirow{3}{*}{ Aylar/Months } & \multicolumn{6}{|c|}{ Sıcaklık/Temperature $\left({ }^{\circ} \mathrm{C}\right)$} & \multirow{2}{*}{\multicolumn{2}{|c|}{$\begin{array}{c}\text { Nispi nem } \\
\text { Relative humidity } \\
\text { (\%) }\end{array}$}} & \multirow{2}{*}{\multicolumn{2}{|c|}{$\begin{array}{c}\text { Toplam yağış } \\
\text { Total precipitation } \\
(\mathrm{mm})\end{array}$}} \\
\hline & \multicolumn{2}{|c|}{ Ortalama Average } & \multicolumn{2}{|c|}{$\begin{array}{l}\text { Maksimum } \\
\text { Maximum }\end{array}$} & \multicolumn{2}{|c|}{ Minimum Minimum } & & & & \\
\hline & $\begin{array}{l}2014- \\
2015\end{array}$ & $\begin{array}{l}2015- \\
2016\end{array}$ & $\begin{array}{l}2014- \\
2015\end{array}$ & $\begin{array}{c}2015- \\
2016\end{array}$ & $\begin{array}{l}2014- \\
2015\end{array}$ & $\begin{array}{l}2015- \\
2016\end{array}$ & $\begin{array}{l}2014- \\
2015\end{array}$ & $\begin{array}{l}2015- \\
2016\end{array}$ & $\begin{array}{l}2014- \\
2015\end{array}$ & $\begin{array}{l}2015- \\
2016 \\
\end{array}$ \\
\hline Eylül/Sep. & 19.9 & 23.0 & 35.9 & 36.0 & 5.2 & 11.0 & 50.9 & 40.8 & 29.8 & 1.0 \\
\hline Ekim/Oct. & 13.7 & 14.5 & 25.6 & 27.3 & -0.8 & 3.9 & 67.0 & 63.3 & 37.2 & 30.8 \\
\hline Kasım/Nov. & 6.5 & 7.5 & 18.7 & 20.3 & -2.8 & -3.6 & 73.8 & 58.1 & 28.4 & 8.2 \\
\hline Aralık/Dec. & 5.9 & -1.1 & 14.4 & 11.7 & -5.0 & -9.6 & 88.2 & 80.5 & 29.2 & 9.1 \\
\hline Ocak/Jan. & 1.2 & -0.2 & 14.7 & 13.7 & -15.0 & -17.2 & 85.6 & 76.2 & 35.2 & 122.3 \\
\hline Şubat/Feb. & 3.5 & 6.0 & 17.5 & 20.6 & -11.5 & -7.5 & 77.6 & 70.8 & 38.3 & 36.4 \\
\hline Mart/Mar. & 7.0 & 7.1 & 23.6 & 24.5 & -4.7 & -7.0 & 76.2 & 60.7 & 89.0 & 43.8 \\
\hline Nisan/Apr. & 8.8 & 13.8 & 24.4 & 28.3 & -3.0 & -0.3 & 66.2 & 47.4 & 26.8 & 23.8 \\
\hline Mayıs/May. & 16.0 & 14.9 & 32.2 & 28.1 & 2.2 & 4.6 & 58.1 & 63.7 & 39.2 & 98.0 \\
\hline Haziran/Jun. & 18.4 & 21.0 & 28.3 & 36.2 & 8.4 & 6.8 & 66.9 & 53.0 & 161.4 & 16.1 \\
\hline Temmuz/Jul. & 23.0 & 24.2 & 36.7 & 36.7 & 11.7 & 11.9 & 47.0 & 42.5 & 20.6 & 5.8 \\
\hline Ağustos/Aug. & 24.8 & 25.7 & 36.3 & 36.8 & 9.8 & 13.4 & 47.5 & 43.8 & 11.8 & 0.0 \\
\hline $\begin{array}{l}\text { Ort/Top. } \\
\text { Ave./Sum }\end{array}$ & 12.4 & 13.0 & & & & & 67.1 & 58.4 & 546.9 & 395.3 \\
\hline
\end{tabular}

Denemenin yürütüldüğü yıllarda ortalama sıcaklık ve nem değerlerinde önemli farklııklar gözlenmezken yağış miktarında kolza tarımını etkileyebilecek önemli değişimler gözlenmiştir.

Kolza her iki yılda da eylül ayının 2. haftasında ekimi gerçekleştirildiğinden, 2014 yılı Eylül ayında yağış ve sıcaklık çıkış için yeterli iken, 2015 yılı Eylül ayında ise yağışın $1 \mathrm{~mm}$ olarak gerçekleşmesi çıkışın gecikmesine neden olmuştur. Aynı zamanda, 2014 yılında erken donlar ekim ayında gözlenirken denemenin ikinci yılında ise kasım ayında gözlenmiştir. Her iki yılda da en soğuk dönemin ocak ayında olduğu ve en düşük sıcaklığın 2015 yılında $-15.0^{\circ} \mathrm{C}, 2016$ yılında ise $-17.2{ }^{\circ} \mathrm{C}$ olarak gerçekleştiği görülmektedir.

Araştırma tesadüf blokları deneme desenine göre 3 tekerürlü olarak kurulmuş ve 8 adet kışlık kolza çeşidi (Atenzo, Champlain, Elvis, EsMercure, Excalibur, PR46W10, PR46W31, Recordie) kullanılmıştır. Araştırmada kullanılan çeşitlerden Atenzo ve EsMercure Fransa, Recordie Almanya,
Champlain ve Elvis Hollanda, Excalibor Litvanya, PR46W10 ve PW46W31 Ingiltere ve Recordie İtalya orjinli olup, Tohumluk Tescil ve Sertifikasyon Merkez Müdürlüğünden temin edilmiştir. Ekimler, kolza tohumları kış soğuklarından daha az zarar görmesi için eylül ayının 2. haftasında (10 Eylül 2014 ve 14 Eylül 2015) gerçekleştirilmiştir. Araştırma alanı nadas alanı olup, ekimden önce rotatiller (rotovatör) ile sürülmüş ve düz toprak yüzeyi için merdane kullanılmıştır. Bölgede genel olarak, yaz kuraklığı nedeniyle toprakta yeterli nemin bulunmaması nedeniyle yeterli tavın sağlanması ve homojen bir çıkışın olması için ekimden sonra her iki deneme, yılında da bir defa (ekim sonrası) yağmurlama sulama yapılmıştır. Parseller $6 \mathrm{~m}$ uzunluğunda olup, $40 \mathrm{~cm}$ sıra aralığı ile 6 sıradan oluşmuştur. Ekim, markörle açılan sıralara elle, dekara $1 \mathrm{~kg}$ tohum hesabıyla yapılmıştır. Araştırmada, parsellere yarısı (6 $\mathrm{kg} \mathrm{da}^{-1} \mathrm{~N}$ ) ekimle beraber, diğer yarısı ilkbaharda (6 kg da-1 $\mathrm{N}$ ), çiçeklenme 
başlangııından hemen önce, olmak üzere $12 \mathrm{~kg}$ $\mathrm{da}^{-1}$ saf azot ve tamamı ekimle beraber $6 \mathrm{~kg} \mathrm{da}^{-1}$ fosfor $\left(\mathrm{P}_{2} \mathrm{O}_{5}\right)$ uygulanmıştır. Sonbahar ekiminde gübre kaynağı olarak diamonyum fosfat (DAP 18/46), triple süper fosfat (TSP) ve üre (\%46) kullanılırken ilkbahar üst gübre olarak amonyum nitrat (AN \%33) gübreleri kullanılmıştır. Çıkış sonrası kış dönemine gelmesi, ilkbahar döneminde ise kolzanın hızlı gelişimi ile sıraları mükemmel kapatması nedeniyle yabancı ot sorunu olmamıştır. Araştırmada, parsellerden rastgele seçilen on bitkide, bitki boyu $(\mathrm{cm})$, yan dal sayısı (adet bitki ${ }^{-1}$ ), kapsül sayısı (adet bitki ${ }^{-1}$ ), kapsülde tane sayısı (adet), bin tane ağırlığı (g), parsel kenar tesiri çıkarıldıktan sonra kalan alandan, tohum verimi ( $\mathrm{kg} \mathrm{da}{ }^{-1}$ ), ham yağ oranı (\%, Soxhlet ekstrakt yöntemi) ve ham yağ verimi $\left(\mathrm{kg} \mathrm{da}{ }^{-1}\right)$, değerleri elde edilmiştir. Elde edilen veriler tesadüf blokları deneme metoduna göre, MSTAT-C paket programında varyans analizine tabi tutulmuştur (Russell, 1986). Uygulamalar arasındaki farklılıklar Duncan karşılaştırma testine göre gruplandırılarak değerlendirilmiştir (Düzgüneş ve ark., 1987).

\section{Araştırma Bulguları ve Tartışma}

Araştırmada yıllar arasında farkın önemli çıkmasından dolayı yıllar ayrı olarak incelenmiş ve değerlendirilmiştir. Çeşitlerin bitki boyu değişimi her iki yılda da istatistiksel anlamda önemli $(P<0.01)$ bulunmuş ve 2014-2015 tarım yılında çeşitlerin daha yüksek boylanma gösterdikleri saptanmıştır (Çizelge 3). 2015-2016 tarım yılı çeşitlerin bitki boyunda kısalma yanında farklılıklarında gözlendiği yıl olmuştur. Denemenin ilk yılında çeşitlerin en yüksek ve en düşük değerleri arasındaki fark yaklaşık $16 \mathrm{~cm}$ iken denemenin ikinci yılında, bu fark $24 \mathrm{~cm}$ olmuştur. Aradaki fark sayısal olarak az olsa da denemenin ikinci yılında ortalama bitki boyundaki düşüşte dikkate alındığında çeşitlerin performansları açısından, ikinci yılın daha zorlu geçtiğinin işaretidir.

Çizelge 3. Çeşitlere ait varyans analiz sonuçları ve ortalamalara ait karşılaştırma

Table 3. Summary of analysis of variance and mean comparison of the rapeseed cultivars

\begin{tabular}{|c|c|c|c|c|c|c|c|c|}
\hline \multirow[t]{2}{*}{$\begin{array}{l}\text { Çeşitler } \\
\text { Cultivars }\end{array}$} & \multicolumn{2}{|c|}{$\begin{array}{c}\text { Bitki boyu }(\mathrm{cm}) \\
\text { Plant height }(\mathrm{cm})\end{array}$} & \multicolumn{2}{|c|}{$\begin{array}{l}\text { Yan dal sayısı } \\
\text { (adet bitki } i^{-1} \text { ) } \\
\text { Branches number } \\
\text { (number plant }^{-1} \text { ) }\end{array}$} & \multicolumn{2}{|c|}{$\begin{array}{c}\text { Bitkide kapsül sayısı } \\
\text { (adet bitki }{ }^{-1} \text { ) } \\
\text { Pod number } \\
\text { (number plant }{ }^{-1} \text { ) }\end{array}$} & \multicolumn{2}{|c|}{$\begin{array}{l}\text { Kapsülde dane sayısı } \\
\text { (adet kapsül }{ }^{-1} \text { ) } \\
\text { Seed number } \\
\text { (number pod }^{-1} \text { ) }\end{array}$} \\
\hline & 2014-2015 & $2015-2016$ & 2014-2015 & $2015-2016$ & 2014-2015 & $2015-2016$ & 2014-2015 & $2015-2016$ \\
\hline Atenzo & $157.07 a b^{*}$ & $136.93 \mathrm{ac}$ & $8.65 \mathrm{a}$ & 5.80 & $401.88 a b$ & $212.55 \mathrm{a}$ & $27.33 a b$ & $26.93 a b c$ \\
\hline Champlain & $148.93 \mathrm{bc}$ & $132.33 \mathrm{bc}$ & $8.80 \mathrm{a}$ & 5.67 & $416.79 a$ & $215.91 \mathrm{a}$ & $24.60 \mathrm{bc}$ & $24.20 \mathrm{~cd}$ \\
\hline Elvis & $150.2 \mathrm{ac}$ & $124.87 \mathrm{c}$ & $7.57 \mathrm{~b}$ & 4.93 & $342.63 \mathrm{bc}$ & $172.59 \mathrm{~b}$ & $24.13 \mathrm{bc}$ & $27.53 a b$ \\
\hline EsMercure & $148.47 \mathrm{bc}$ & $142.53 \mathrm{ab}$ & $7.73 a b$ & 5.73 & $240.45 d$ & $203.58 a b$ & $26.47 a b$ & $22.20 d$ \\
\hline Excalibur & $142.73 \mathrm{c}$ & $134.53 \mathrm{bc}$ & $7.27 \mathrm{~b}$ & 5.67 & $306.48 \mathrm{c}$ & $169.05 \mathrm{~b}$ & $24.07 \mathrm{bc}$ & $24.40 \mathrm{bcd}$ \\
\hline PR46W10 & 149.47 bc & $140.53 \mathrm{ab}$ & $8.00 a b$ & 5.93 & $331.14 \mathrm{c}$ & $192.45 a b$ & $22.00 \mathrm{c}$ & $23.13 d$ \\
\hline PR46W31 & $156.07 a b$ & $141.40 a b$ & $8.23 a b$ & 5.56 & $410.36 a$ & $225.50 \mathrm{a}$ & $28.13 \mathrm{a}$ & $28.67 \mathrm{a}$ \\
\hline Recordie & 159.07 a & $148.80 \mathrm{a}$ & $8.73 \mathrm{a}$ & 6.05 & $365.34 \mathrm{abc}$ & $198.14 a b$ & $24.53 \mathrm{bc}$ & $26.78 a b c$ \\
\hline Ort./Ave & 150.25 & 137.74 & 8.12 & 5.67 & 351.88 & 198.72 & 25.16 & 25.48 \\
\hline$L S D$ & 8.25 & 11.45 & 0.99 & & 62.18 & 35.31 & 2.96 & 2.94 \\
\hline
\end{tabular}

*. Aynı kolonda aynı harf veya harflerle gösterilen değerler arasında Duncan çoklu karşılaştırma testinde önem seviyesine göre istatistiksel olarak önemli bir fark yoktur.

*. For each main effect, values within same columns followed by the same letter or letters are not statistically significant difference in Duncan multiple comparison test.

Her iki yılda da elde edilen bitki boyu değerleri benzer bölgelerde yapılan kolza araştırmalarının (Başalma, 2004; Çorbaci, 2011; İnan ve ark., 2014;
Gürsoy ve ark., 2015) sonuçlarıyla paralellik göstermektedir. Her iki yılda da en yüksek bitki boyu Recordie çeşidinden elde edilirken en düşük 
bitki boyu ise denemenin ilk yılında Excalibur $(142.73 \mathrm{~cm})$ ve ikinci yılda ise Elvis $(124.87 \mathrm{~cm})$ çeşitlerinden elde edilmiştir.

Çeşitlerin yan dal sayısı değişimi denemenin ilk yılında, $\quad P<0.01$ önem düzeyinde, anlamlı bulunurken denemenin ikinci yılında, yan dal sayısı bakımında çeşitler arasında farklılığın istatistiksel anlamda önemli çıkmadığı saptanmıştır. Araştırmanın ilk yılında, en yüksek dallanma Champlain (8.80 adet bitki ${ }^{-1}$ ), Recordie (8.73 adet bitki $^{-1}$ ) ve Atenzo (8.65 adet bitki ${ }^{-1}$ ) çeşitlerinden gözlenirken en düşük dallanma ise

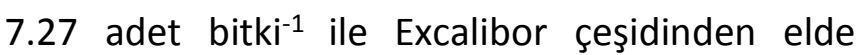
edilmiştir (Çizelge 3). Yan dal sayısı önemli verim kriterlerinden biri olması nedeniyle, yan dal sayısındaki artış kolzada tohum verimini artırmaktadır (Öğütçü ve Kolsarıcı, 1979).

Bitkide kapsül sayısı değişimi araştırmanın her iki yılında da çeşitler arasında farklılık göstermiş ve bu değişim istatistiksel anlamda $P<0.01$ düzeyinde önemli bulunmuştur. Araştırmanın ilk yılında, en yüksek kapsül sayısı Champlain ve PR46W31 çeşitlerinden elde edilirken 2. yılında ise PR46W31, Champlain ve Atenzo çeşitlerinden elde edilmiştir (Çizelge 3). Araştırmanın ikinci yılında, saptanan en yüksek kapsül sayısı değeri, araştırmanın ilk yılında saptanan en düşük kapsül sayısı değerinden daha düşüktür. Bu duruma araştırmanın ikinci yılında sonbahar yağışlarının yetersizliği ile kış öncesi yeterli bitki gelişiminin sağlanamaması ve ilkbahar döneminde erken ısınmaya bağlı erken sapa kalkma ve sonrasın da yaşanan ani don zararı neden olmuştur. Ayrıca ilkbahar sonrası sıcaklıkların yüksek seyretmesi ve yağış yetersizliği bu olumsuz etkiyi artırmıştır. Bu durum, ekim zamanı çalışan araştırmacılar tarafından da gözlenmiş ve bu durumu araştırmacılar geç ekimlerde soğuk nedeni ile dal sayısının ve çiçeklenmenin azaldığı bunun sonucu olarak da kapsül sayısında önemli azalmalar olduğu şeklinde ifade etmişlerdir (Başalma, 2004; Öztürk ve Akınerdem, 2007; Beğbağa ve Öztürk, 2008; Gürsoy ve ark., 2015).

Çeşitlerin kapsülde dane sayıları yönünden farklılıkları her iki yılda da $\mathrm{P}<0.01$ düzeyinde önemli olduğu ve çeşitlerin her iki yıldaki dane sayıları ortalamaları diğer parametrelerin aksine birbirine yakın olduğu belirlenmiştir (Çizelge 3 ). Bunun nedeni olarak da denemenin ikinci yılında yan dal ve kapsül sayısının azalması ile bitkinin kapsülde yeterli dane sayısına ulaşma potansiyelini yakalamasıdır. Kapsülde dane sayılarının 22 ile 28 arasında değiştiği gözlenmiş ve bu değerler benzer şartlarda yapılan çalışmalarla uyum göstermektedir (Öğütçü ve Kolsarıcı, 1979; Sağlam ve ark., 1999; Başalma, 2004, 2006; Coşgun, 2013; Gürsoy ve ark., 2015) . PR46W31 çeşidi her iki yılda da çevresel faktörlerden daha az etkilenerek kapsülde dane sayısını en yüksek düzeyde gerçekleştiren çeşit olmuştur. Kapsülde en düşük tane sayısı ilk yılda 22.00 adet ile PR46W10 iken ikinci yılda ise $\mathbf{2 2 . 2}$ adetle EsMercure çeşidi olmuştur.

Araştırmada kullanılan çeşitlerin bin dane ağırlıklarındaki değişim denemenin ilk yılında $\mathrm{P}<0.05$ düzeyinde önemli bulunurken ikinci yılda ise istatistiksel anlamda önemli çıkmamıştır (Çizelge 4). En yüksek bin tane ağırlığı Atenzo çeşidinden $5.96 \mathrm{~g}$ olarak gerçekleşirken en düşük bin tane ağılığı ise $4.55 \mathrm{~g}$ ile Elvis çeşidinden gerçekleşmiştir. Bin tane ağırlığının, farklı araştırmacılar (Kolsarıcı ve Başalma, 1988; Başalma, 2004; Acar ve ark., 2005; Gizlenci ve ark., 2007; Coşgun, 2013; Gürsoy ve ark., 2015) tarafından $1.7 \mathrm{~g}$ ile $6.0 \mathrm{~g}$ arasında değiştiği bildirilmekle birlikte bulgularımız bu değerlerin üst seviyelerine yakın olduğu görülmektedir.

Çeşitlerin tohum verimleri her iki deneme yılında da çeşitler arasında farklı olduğu ve bu farklığında $\mathrm{P}<0.01$ düzeyinde istatistiksel anlamda önemli olduğu saptanmıştır. Illk yıl en verimli çeşit $2939.17 \mathrm{~kg} \mathrm{ha}^{-1}$ ile PR46W10 olurken en düşük verim ise $1923.13 \mathrm{~kg} \mathrm{ha}^{-1}$ ile Elvis çeşidi olmuştur (Çizelge 4). Illk yıl çeşitlerin verim ortalaması $2566.43 \mathrm{~kg} \mathrm{ha}^{-1}$ iken ikinci yıl çeşitlerin verim ortalaması $1262.00 \mathrm{~kg} \mathrm{ha}^{-1}$ olarak gerçekleşmiştir. Kışlık kolzada yüksek dane verimi, sonbaharda düzenli çıkışı ile birlikte ilk don tarihine kadar gelişmiş kök ve rozet aksamına ulaşması ve kış sonunda büyüme dönemlerini uygun sürelerde tamamlayıp tohum oluşturması ile gerçekleşmektedir. 
Çizelge 4. Çeşitlere ait varyans analiz sonuçları ve ortalamalara ait karşılaştırma Table 4. Summary of analysis of variance and mean comparison of the rapeseed cultivars

\begin{tabular}{|c|c|c|c|c|c|c|c|c|}
\hline \multirow{2}{*}{$\begin{array}{l}\text { Cessitler } \\
\text { Cultivars }\end{array}$} & \multicolumn{2}{|c|}{$\begin{array}{c}\text { Bin tane ağırlı̆̆ } \\
\text { Thousand seed weight (g) }\end{array}$} & \multicolumn{2}{|c|}{$\begin{array}{c}\text { Tohum verimi } \\
\text { Seed yield }\left(\mathrm{kg} \mathrm{ha}^{-1}\right)\end{array}$} & \multicolumn{2}{|c|}{$\begin{array}{c}\text { Ham yağ oranı crude oil } \\
\text { rate (\%) }\end{array}$} & \multicolumn{2}{|c|}{$\begin{array}{c}\text { Ham yağ verimi } \\
\text { Crude oil yield }\left(\mathrm{kg} \mathrm{ha}^{-1}\right)\end{array}$} \\
\hline & 2014-2015 & $2015-2016$ & 2014-2015 & $\begin{array}{l}2015- \\
2016\end{array}$ & 2014-2015 & $2015-2016$ & 2014-2015 & $2015-2016$ \\
\hline Atenzo & $5.96 a^{*}$ & 5.38 & $2809.30 \mathrm{ab}$ & $1357.45 b c$ & $46.37 \mathrm{a}$ & 43.87 & $1302.45 \mathrm{a}$ & $595.22 b$ \\
\hline Champlain & $5.13 \mathrm{bc}$ & 5.01 & $2413.13 b$ & $1118.85 \mathrm{bcd}$ & $46.19 a b$ & 44.93 & $1113.90 \mathrm{~b}$ & 503.22 bc \\
\hline Elvis & $4.55 \mathrm{c}$ & 4.92 & $1923.13 \mathrm{c}$ & $892.92 \mathrm{~d}$ & $45.84 a b$ & 44.98 & $881.00 \mathrm{c}$ & $401.75 \mathrm{c}$ \\
\hline EsMercure & $5.16 \mathrm{bc}$ & 4.78 & $2470.26 a b$ & 1795.37 a & $44.82 \mathrm{abc}$ & 43.88 & $1107.03 \mathrm{~b}$ & $788.46 \mathrm{a}$ \\
\hline Excalibur & $5.00 \mathrm{bc}$ & 4.83 & $2469.06 \mathrm{ab}$ & $1217.14 \mathrm{bcd}$ & $45.17 \mathrm{abc}$ & 43.86 & $1114.33 \mathrm{~b}$ & $533.90 \mathrm{bc}$ \\
\hline PR46W10 & $5.49 \mathrm{ab}$ & 5.28 & 2939.17 a & $1240.52 b c$ & $43.15 \mathrm{c}$ & 43.09 & $1268.14 \mathrm{a}$ & $533.87 \mathrm{bc}$ \\
\hline PR46W31 & $5.21 \mathrm{bc}$ & 4.94 & $2843.23 a b$ & $1014.32 \mathrm{~cd}$ & $43.99 \mathrm{bc}$ & 43.52 & $1251.09 \mathrm{a}$ & $441.22 \mathrm{c}$ \\
\hline Recordie & $5.03 \mathrm{bc}$ & 4.45 & $2664.17 \mathrm{ab}$ & $1459.43 \mathrm{~b}$ & $46.47 \mathrm{a}$ & 44.55 & $1238.56 \mathrm{a}$ & $649.55 \mathrm{~b}$ \\
\hline Ort. Ave. & 5.19 & 4.95 & 2566.43 & 1262.00 & 45.25 & 44.09 & 1159.56 & 555.90 \\
\hline$L S D$ & 0.66 & & 448.60 & 316.70 & 1.49 & & 62.58 & 138.10 \\
\hline
\end{tabular}

Denemenin ikinci yılında sonbaharda bitki gelişimi için yeterli yağışın olmaması, kış mevsiminin daha soğuk olması, ilkbahar döneminde erken sıcaklık artışına rağmen ani don zararları yan dal ve kapsül sayısını olumsuz etkilemiş ve denemenin ilk yılına göre tohum verimi $\% 50$ daha düşük gerçekleşmiştir. Denemenin ikinci yılında düşen tohum verimine rağmen en yüksek verim $1795.37 \mathrm{~kg} \mathrm{ha-1}$ ile EsMercure çeşidinden elde edilirken en düşük verim ise $892.92 \mathrm{~kg} \mathrm{ha}^{-1}$ ile Elvis çeşidinden elde edilmiştir. Elvis çeşidi genel olarak her iki yılda da en düşük tohum verimini sağladığı görülmektedir. Yapılan çalışmalarda kolzanın tohum veriminin Acar ve ark. (2005) 845-4810 kg ha-1; Baydar (2005) 2180-2872 kg ha-1; Gül ve ark. (2005) 1302$2926 \mathrm{~kg} \mathrm{ha}^{-1}$; Başalma (2006) 2243-2588 kg ha-1; Gizlenci ve ark. (2007) 1893-3238 kg ha-1; Gürsoy ve ark. (2015) 2237-2467 kg ha-1; aralığında değiştiğini bildirmişlerdir. Araştırma sonuçlarımız Türkiye'nin farklı bölge ve yıllarında yapılan bu çalışmalarla paralellik göstermektedir (Sağlam ve ark., 1999; Tunçtürk ve ark., 2005).

Çeşitlerin ham yağ oranı iki yıllık araştırma süresinde 43.09 ile $46.47 \%$ arasında değişim göstermiş ve bu değişimlerde ilk yıl sonuçların istatistiksel anlamda $\mathrm{P}<0.01$ düzeyinde önemli bulunmuştur (Çizelge 4). En yüksek ham yă̆ içeriği Recordio ve Atenzo çeşitlerinden sırasıyla
\%46.47 ve \%46.37 olarak gerçekleşmiştir. Çeşitlerin ham yağ içeriği genetik özellikler yanında çevresel koşullardan da etkilenmektedir. Özellikle kışlık kolzada ekim zamanı için yapılan çalışmalarda ekim zamanı gecikmesi ile ham yağ oranının azaldığı belirtilmiştir (Acar ve ark., 2005; Beğbağa ve Öztürk, 2008; Gürsoy ve ark., 2015). Denemenin ikinci yılında gözlenen farklııkta benzer şekilde sonbahar yağışlarının yetersizliği nedeniyle bitkinin kışa güçlü kök sitemi ve rozet dönemiyle girememesinden kaynaklanmaktadır. Araştırma sonucunda çeşitlerin ham yağ içeriği ise benzer çalışmalardan elde edilen sonuçlarla (Kolsarıcı ve Başalma, 1988; Başalma, 2004; Acar ve ark., 2005; Gül ve ark., 2005; Başalma, 2006; Gizlenci ve ark., 2007; Çorbaci, 2011; Gürsoy ve ark., 2015) uyum göstermektedir.

Tohum verimi ve yağ oranının ortak bir fonksiyonu olarak hesaplanan yağ verimi değerlerinin çeşitlere göre farklılık göstermesi araştırmanın yürütüldüğü her iki yılda da $\mathrm{P}<0.01$ düzeyinde önemli bulunmuştur (Çizelge 4). Tohum veriminin çarpan olmasından dolayı tohum verimindeki yıllar arasındaki yaklaşık \%50 düzeyindeki farklılık ham yağ veriminde de yansımıştır. Denemenin ilk yılında sırasıyla Atenzo (1342.45 kg ha-1), PR46W10 (1268.14 kg ha-1), PR46W31(1251.09 kg ha-1), RECORDIE (1238.56 kg $\left.\mathrm{ha}^{-1}\right)$ çeşitleri, ikinci yılda ise EsMercure $(788.46 \mathrm{~kg}$ 
$\mathrm{ha}^{-1}$ ) çeşidi en yüksek ham yağ verimi sağlayan grupta yer almıştır. Kolza çeşitlerinin yetişme döneminde karşılaştığı herhangi bir stres faktöründe farklı tepkiler gösterebileceği bu çalışmada gözlenmiştir. Genel olarak Elvis çeşidi her iki yılda da en düşük ham yağ verimi sağlayan grubu oluştururken, denemenin ikinci yılında PR46W31 çeşidi diğer en düşük grupta yer alan çeşit olmuştur. Pr026w31 çeşidi ilk yılda en yüksek ham yağ verimi sağlayan grupta yer alırken ikinci yılda tam tersi bir verimle en düşük grupta yer almıştır.

\section{Sonuçlar}

Bitkisel yağ talebinin karşılanması için alternatif alanlarda alternatif yağlı tohumlu bitkilerin kullanım fırsatlarının oluşturulması kapsamında Kırşehir ekolojik koşullarında ilk defa denenen kışık kolza çeşitlerinden bölgeye uygun çeşitlerin belirlenmesi amaçlanmıştır. Çalışmada kullanılan 8 adet kışlık kolza çeşidi verim ve verim parametreleri yönünden değerlendirildiğinde Kırşehir ekolojik koşullarda yapılan çalışma sonuçlarının Türkiye'nin diğer yörelerinde yapılan araştırma sonuçlarına göre tohum ve ham yağ veriminin farklı olmadığı görülmüştür. Kırşehir ilinde yaklaşık 250 bin ha alanda tahıllar tarımı yapılırken yaklaşık 100 bin ha alan ise nadasa bırakılmaktadır. Uygun kışlık kolza çeşidinin ekim nöbetine sokulması ile bu alanların değerlendirilmesi ve ekonomik getiri yönünden önemlidir. Bölgenin en önemli kolza yetiştiriciliği sorunu sonbaharda yağış yetersizliği nedeniyle çıkışların gecikmesi ve yeterli gelişimi sağlayamadığından don zararının artmasıdır. Benzer durum araştırmamızda da yaşanmış ve ikinci yılda tohum verimi denemenin birinci yılına göre yaklaşık \%50 daha düşük olduğu gözlenmiştir. Sonbahar yağışlarının sadece çıkış için değil aynı zamanda bitkinin kış öncesi güçlü kök sistemi ve rozet dönemine ulaşması açısından da önemlidir. Kırşehir ve benzer ekolojiler için sonbaharda yetersiz yağıs ve ilkbaharda ani don hadisesi dikkate alındığında hem tohum hem de yağ verimi yönünden daha üstün grupta yer alan
EsMercure, Atenzo, PR46W10 ve Recordie çeşitleri önerilmektedir.

Çıkar Çatışması Beyanı: Makale yazarları aralarında herhangi bir çıkar çatışması olmadığını beyan ederler.

\section{Kaynaklar}

Acar, M., Gizlenci, Ş., ve Dok, M. (2005). Orta Karadeniz Geçit Bölgesinde Kolza İçin En Uygun Ekim Zamaninin Belirlenmesi. Selcuk Journal of Agriculture and Food Sciences, 19(36), 110-115.

Başalma, D. (2004). Kışlık kolza (Brassica napus ssp. oleifera L.) Çeşitlerinin ankara koşullarında verim ve verim öğeleri yönünden karşılaştırılması. Tarım Bilimleri Dergisi, 10(2), 211-217.

Başalma, D. (2006). Kışlık kolzada (Brassica napus ssp. oleifera L.) ekim sıklığı, verim ve verim öğeleri arasındaki ilişkiler. Akdeniz Üniversitesi Ziraat Fakültesi Dergisi, 19(2), 191-198.

Baydar, H. (2005). Isparta koşullarında kanola (Brassica napus L.) çeşitlerinin verim ve kalite özellikleri. Süleyman Demirel Üniversitesi Fen Bilimleri Enstitüsü Dergisi, 9(3), 1-6.

Beğbağa, M., ve Öztürk, Ö. (2008). Ege Bölgesi Koşullarinda Bazi Kişlik Kolza Çeşitlerinde Farkli Ekim Zamani Uygulamalarinin Verim, Verim Unsurlari ve Kalite Üzerine Etkileri. Selçuk Tarım Bilimleri Dergisi, 22(44), 84-98.

Coşgun, B. (2013). Bazı kışlık kolza çeşitlerinde verim, verim unsurları ve kalite özelliklerinin belirlenmesi. Selçuk Üniversitesi Fen Bilimleri Enstitüsü.

Çorbaci, S. (2011). Tekirdağ koşullarında mikrobiyal ve kimyasal gübre uygulamasının kolza (Brassica napus ssp. Oleifera L.) bitkisinin verim ve kalite özelliklerine etkisi. Namık Kemal Üniversitesi, Fen Bilimleri Enstitüsü, Tarla Bitkileri Ana Bilim Dalı, Yüksek Lisans Tezi, 65sy.

Düzgüneş, O., Kesici, T., Kavuncu, O., ve Gürbüz, F. (1987). Araştırma ve deneme metodları (İstatistik MetodlarıII). Ankara Üniversitesi Ziraat Fakültesi Yayınları, 1021, 295.

FAO. (2019). Statistics Division of Food and Agriculture Organization of the United Nations. Available online:http://www.fao.org/faostat/en/\#data/QC (Erişim tarihi: 12.07.2019).

Gizlenci, Ş., Acar, M., Dok, M., ve Aygün, Y. (2007). Ülkesel Kolza Adaptasyon Projesi Karaedeniz Bölgesi Sonuç Raporu. Türkiye VII. Tarla Bitkileri Kongresi, 25-27.

Gül, M., Egesel, C., ve Kahraman, F. (2005). Çanakkale Yöresinde Yeni Kışlık Kolza Çeşitlerinde Bazı Özelliklerin Araştırılması. MK Ü. Ziraat Fakültesi Dergisi, 10(1-2), 1-8.

Gürsoy, M., Nofouzi, F., ve Başalma, D. (2015). Ankara koşullarında kışlık kolzada uygun ekim zamanının belirlenmesi. Tarla Bitkileri Merkez Araştırma Enstitüsü Dergisi, 24(2), 96-102.

İnan, M., Kirpik, M., Çelik, A., ve Büyük, G. (2014). Adıyaman koşullarında yazlık-kışlık kolza (Brassica sp.) 
çeşitlerinde verim ve verim öğelerinin belirlenmesi. Türk Tarım ve Doğa Bilimleri Dergisi, 1(1), 79-84.

Kolsarıcı, Ö., ve Başalma, D. (1988). Yabancı kökenli yazlık çeşitlerinin tohum verimi ile bin tohum ağırlığının saptanması. Ankara Üniv, Zir, Fak, Yıllığı, 39(1-2), 255-265.

Öğütçü, Z., ve Kolsarıcı, Ö. (1979). Kışlık kolza çeşitlerinin Antalya, Edirne ve Ankara şartlarına adaptasyonu. TC Gıda-Tarım ve Hayvancılık Bakanlığı Tarımsal Araştırma Dergisi, 1(3), 175-188.

Öztürk, Ö., ve Akınerdem, F. (2007). Bazı kışıık kolza çeşitlerinde farklı ekim zamanlarında verim ile morfolojik özellikler arasındaki ilişkilerin incelenmesi. Türkiye VII. Tarla Bitkileri Kongresi, 25-27.
Russell, D. (1986). MSTAT-C package programme. Crop and Soil Science Department, Michigan State University, USA.

Sağlam, C., Arslanoğlu, F., ve Kaba, S. (1999). Kışlık Kolza Çeşitlerinin Tekirdağ Koşullarına Adaptasyonu. Türkiye, 3, 15-18.

TUik. (2019). Türkiye İstatistik Kurumu. https://biruni.tuik.gov.tr/medas/?kn=104\&locale=tr, (Erişim tarihi: 19.07.2019).

Tunçtürk, M., Yımaz, i., Erman, M., ve Tunçtürk, R. (2005). Yazlık kolza (Brassica napus ssp. oleifera L.) çeşitlerinin Van ekolojik koşullarında verim ve verim özellikleri yönünden karşılaştırılması. Tarım Bilimleri Dergisi, 11(1), 78-85. 